\title{
Comparative demography of the exotic Harmonia axyridis with other aphidophagous coccinellids reared on artificial diet
}

\author{
Julianne Milléo(1), Francisco Sales Fernandes ${ }^{(2)}$ and Wesley Augusto Conde Godoy(2)
}

\begin{abstract}
(1)Universidade Estadual de Ponta Grossa, Departamento de Biologia Geral, Rua Carlos Cavalcanti, 4.748, CEP 84030-900, Ponta Grossa, PR, Brazil. E-mail: jmilleo@hotmail.com (2)Universidade de São Paulo, Escola Superior de Agricultura Luiz de Queiroz, Departamento de Entomologia e Acarologia, Avenida Pádua Dias, 11, CEP 13418-900, Piracicaba, SP, Brazil. E-mail: salimfernandes@hotmail.com, wacgodoy@usp.br
\end{abstract}

\begin{abstract}
The objective of this work was to compare biological aspects and life table parameters of the coccinellids Harmonia axyridis, Cycloneda sanguinea and Hippodamia convergens. Insects were fed eggs of Anagasta kuehniella, and reared at $24.5 \pm 1{ }^{\circ} \mathrm{C}, 70 \pm 10 \%$ relative humidity, with a 12-hour photophase. Hippodamia convergens took about 1.6-day to complete development, longer than $H$. axyridis, and 2.4-day longer than $C$. sanguinea. At immature stages, $H$. axyridis exhibited the highest survival percentage (49.2\%), in comparison to the other coccinellids. For mean adult longevity, H. convergens was deficient, in comparison with the other species. Mean period of pre-oviposition was the longest in C. sanguinea; the longest oviposition time occurred for H. axyridis; and the post-oviposition period was similar between the coccinellids. Considering the reproductive parameters, $H$. axyridis showed the best performance in all aspects. For life table, the values of $H$. convergens were higher than, although close, to those of $H$. axyridis. Nevertheless, the high net reproductive rate of $H$. axyridis showed this species potential to increase population size. The biological characteristics of the exotic $H$. axyridis favors its invasion and establishment in Brazil, corroborating results noticed in other countries.

Index terms: Cycloneda sanguinea, Hippodamia convergens, biological control, developmental stages, invasive species, life table.

\section{Demografia comparativa da exótica Harmonia axyridis com outros coccinelídeos afidófagos criados com dieta artificial}

\begin{abstract}
Resumo - O objetivo deste trabalho foi comparar aspectos biológicos e parâmetros da tabela de vida dos coccinelídeos Harmonia axyridis, Cycloneda sanguinea e Hippodamia convergens. Os insetos foram alimentados com ovos de Anagasta kuehniella e criados a $24,5 \pm 1^{\circ} \mathrm{C}$, à umidade relativa de $70 \pm 10 \%$, com fotófase de 12 horas. Para completar o desenvolvimento, $H$. convergens levou aproximadamente 1,6 dia a mais do que $H$. axyridis, e 2,4 dias a mais do que $C$. sanguinea. Nos estágios iniciais, $H$. axyridis apresentou a maior percentagem de sobrevivência $(49,2 \%)$, em comparação aos outros coccinelídeos. Quanto à longevidade média de adultos, $H$. convergens foi deficiente, em comparação às outras espécies. A média do período de pré-oviposição foi mais longo em C. sanguínea; o tempo de oviposição mais longo ocorreu em $H$. axyridis; e o período de pós-oviposição foi similar entre os coccinelídeos. Considerando-se os parâmetros reprodutivos, H. axyridis apresentou a melhor performance em todos os aspectos. Quanto à tabela de vida, os valores de $H$. convergens foram mais altos, embora aproximados dos de $H$. axyridis. No entanto, a alta taxa líquida de reprodução de $H$. axyridis mostrou o potencial desta espécie para aumentar o tamanho populacional. As características biológicas de $H$. axyridis favorecem a invasão e o estabelecimento dessa espécie exótica no Brasil, o que corrobora os resultados observados em outros países.
\end{abstract}

Termos para indexação: Cycloneda sanguínea, Hippodamia convergens, controle biológico, fases de desenvolvimento, espécie invasora, tabela de vida.

\section{Introduction}

The Coccinellidae family (Coleoptera) is of great economic and ecological importance, due principally to the predatory habit exhibited by the majority of them. There is a substantial variety of consumed prey, but coccinelids feed on mostly aphids and coccids (Hemiptera) (Almeida \& Ribeiro-Costa, 2009). Many coccinellids prey on pests of agricultural concern and are well-known biological control agents with various successful cases described in the literature (Roy \& Migeon, 2010). 
Harmonia axyridis (Pallas 1773) (Coleoptera: Coccinellidae), originally from Central Asia, has been introduced in many countries for the control of aphids and other insect pests, but recent reports indicate that the species has caused serious problems for the native insect community (Vilcinskas et al., 2013). Despite the benefits it offers as a biological control agent, $H$. axyridis is perhaps better know for its adverse impacts. Koch \& Galvan (2008) reviewed the North American experience with $H$. axyridis, focusing on these adverse impacts, which have been arranged into three general categories: on non-target arthropods, on fruit production, and impacts as a household invader.

In the Americas, $H$. axyridis was introduced in 1916 in California. However, in the 1970s and 1980s, introductions of this species were carried out more often in other parts of the United States and Canada, and later in Mexico (Koch et al., 2006). In South America, it was introduced intentionally in Mendoza, Argentina, at the end of the 1990s, for aphid control; and in 2001, its presence was recorded in Buenos Aires (Saini, 2004). In Brazil, this coccinelid was detected for the first time in Curitiba, PR, in April 2002, feeding on the aphid Tinocallis kahawaluokalani (Kirkaldy, 1907) (Hemiptera: Aphididae) (Almeida \& Silva, 2002). Since then, $H$. axyridis has been found in various municipalities, in the states of the Central-West, Southeast and South regions of the country (Milléo et al., 2008; Martins et al., 2009; Bernardi et al., 2010; Koch et al., 2011). More recently, it was recorded in other South American countries including Chile (Grez et al., 2010), Uruguay (Nedved \& Krejèik, 2010), Colombia (Amat-García et al., 2011), Peru (Iannacone \& Perla, 2011) and Ecuador (González \& Kondo, 2012).

The interest on studying this insect has been due to many reasons, such as its efficiency in the control of aphids, its high capacity of dissemination in different habitats, and his effect on intraguild interactions. Its relatively large size, aggressive behavior, extreme polyphagy, and effective strategies of physical and chemical defense make $H$. axyridis an exceptional predator and competitor (Pell et al., 2008).

Hippodamia axyridis impacts other species indirectly through competition, and directly through intraguild predation. Performed surveys in different areas around the world indicate increases of $H$. axyridis and decreases of native species (Milléo et al., 2008;
Martins et al., 2009; Almeida \& Ribeiro-Costa, 2009; Bernardi et al., 2010).

Cycloneda sanguinea (Linnaeus, 1763) and Hippodamia convergens Guerin-Meneville, 1842 (Coleoptera: Coccinellidae), are native to the Nearctic and Neotropical regions and play an important role as generalist predators of hemipterans. Before the recording of $H$. axyridis in Brazil, these species were abundant in surveys of insects associated with aphids in the country (Mendes et al., 2000; Michelotto et al., 2003; Guerreiro et al., 2005).

A better understanding of the coexistence mechanisms between $H$. axyridis and native coccinellids is essential to reduce possible negative effects on native species (Pell et al., 2008; Meisner et al., 2011). Proposals by Pell et al. (2008) suggest that pest management strategies, aimed at maintaining predator diversity through habitat manipulation, and the diversification of our agricultural landscapes could help decline predator diversity associated with the arrival of $H$. axyridis.

Accordingly, comparative analysis of the performance of an exotic species in relation to local species provides information on species potential population growth and mechanisms of intraguild competition. For this reason, $H$. axyridis has been the subject of extensive research in Europe and North America (Koch, 2003; Lanzoni et al., 2004; Koch et al., 2006; Koch \& Galvan, 2008). However, Brazil lacks studies on the interaction of $H$. axyridis with local fauna, including the guild of predatory insects. Studies involving demographic parameters, such as those obtained by designing life tables are thus of utmost importance for the knowledge of introduced species potential, mainly with respect to their ability to compete, to prey and even to exclude other species.

The objective of this work was to compare biological aspects and life table parameters of the coccinellids Harmonia axyridis, Cycloneda sanguinea and Hippodamia convergens.

\section{Materials and Methods}

Adults of the three species of Coccinellini (C. sanguinea, $H$. axyridis, and $H$. convergens) were collected in March 2012 on sorghum [Sorghum bicolor (L.) Moench.], at Fazenda Areão, (22 42'30"S, $\left.47^{\circ} 30^{\prime} 00^{\prime \prime} \mathrm{W}\right)$, an area close to the Campus of the 
Escola Superior de Agricultura Luiz de Queiroz (Esalq), Piracicaba, SP, Brazil.

After collection, the insects were transported to the Laboratório de Ecologia de Insetos (Esalq), where the species were separated into couples. Each couple was stored in $9 \mathrm{~cm}$ Petri dishes, in moistened cotton with a honey-water solution (50\%), and daily fed ad libitum with frozen eggs of Anagasta kuehniella (Zeller) (Lepidoptera: Pyralidae). The alternative diet was chosen, due to the positive results obtained by Kato et al. (1999) for H. convergens and by Santos et al. (2009) for $H$. axyridis, as well as the ease of obtaining and their neutrality in preference for the three coccinellids, since in the field these species are not fed with this diet.

Breeding stock was maintained in an acclimatized room at $24.5 \pm 11^{\circ} \mathrm{C}, 70 \pm 10 \%$ relative humidity, and 12-hour photophase. Petri dishes were changed every 48 hours, and the observations were made daily. The trials were conducted according to availability of species. From the second generation, 10 couples of each species were formed (10 replicates per species), with adults selected from different maternal lines to avoid cosanguinity. Each couple was kept in a $9 \mathrm{~cm}$ Petri dish and daily fed ad libitum with eggs of $A$. kuehniella. The number of eggs laid per female was recorded daily until death. Egg clusters were separated daily from the adults to prevent cannibalism on the eggs. Male deaths during the experimental period were recorded, and replaced until the death of females to continue with the registry of postures.

The number of hatched larvae from these eggs was determined by analysing the viability (number of eggs hatched $\times 100 /$ number of eggs laid) for each species. Starting with the second oviposition, larvae were randomly selected, and on alternate days, 10 recently hatched larvae of each couple (totaling 100 larvae of the $1^{\text {st }}$ instar of each species $=100$ replicates per species) were individualized in Petri dishes; larvae also fed ad libitum on eggs of A. kuehniella, and were examined daily to determine ecdyses. Deaths were recorded, and the individuals were replaced with new larvae of the $1^{\text {st }}$ instar because only the larvae that reached adult age were considered for determining the development time of each stage.

The following biological variables were evaluated: period of incubation and viability of eggs; duration and viability of each instar; sex ratio (number of females in
100); longevity of adults; periods of pre-oviposition; oviposition and post-oviposition; fecundity (mean number of laid eggs per female); and fertility (mean number of viable eggs). These data were used to construct life tables.

After verification of data normality and homogeneity by the tests of Shapiro-Wilk (W) and Bartlett, respectively; means were subjected to analysis of variance and compared by Tukey's test, at $5 \%$ probability. Results showing no normal tending distribution, even after data transformation, were subjected to the nonparametric Kruskal-Wallis test, with the means of the ranked data compared at 1 or $5 \%$ probability. Analysis employed the R 2.13.1 statistical program (R Development Core Team, 2011).

The fertility in the life table was calculated using the TabVida computational system (Penteado et al., 2010) as follows: specific fertility $\left(\mathrm{m}_{\mathrm{x}}=\right.$ number of descendent produced per female at age $\mathrm{x}$ and that result in females); survival rate $\left(1_{\mathrm{x}}=\right.$ life expectancy to age $\mathrm{x}$, expressed as fraction of an initial population of one female); net reproductive rate $\left[\mathrm{R}_{\mathrm{o}}=\Sigma\left(\mathrm{m}_{\mathrm{x}} \mathrm{l}_{\mathrm{x}}\right)\right]$; time interval between each generation $\left[\mathrm{T}=\left(\Sigma \mathrm{m}_{\mathrm{x}} \mathrm{l}_{\mathrm{x}} \mathrm{x}\right) / \Sigma\left(\mathrm{m}_{\mathrm{x}} \mathrm{l}_{\mathrm{x}}\right)\right]$; innate capacity for increase in numbers $\left(r_{m}=\log R_{o} / T\right)$; finite ratio of population increase $\left(\lambda-\mathrm{e}^{\mathrm{rm}}\right)$; and population doubling time $\left[\mathrm{TD}=\log (2) / \mathrm{r}_{\mathrm{m}}\right]$.

\section{Results and Discussion}

The development periods (egg-adult) differed between the three species (Table 1). To complete its development, $H$. convergens took about 1.6-day longer than $H$. axyridis and 2.4-day longer than $C$. sanguinea. In general, $H$. convergens had the longest larval stage compared to the other species. Significant differences were found for the incubation period, $1^{\text {st }}$ instar, $2^{\text {nd }}$ instar, $3^{\text {rd }}$ instar and $4^{\text {th }}$ instar. However, there was a longer pre-pupal period in $C$. sanguinea and longer pupal period in $H$. axyridis.

The highest percentage of females was shown by $H$. axyridis (54\%), followed by $H$. convergens $(50 \%)$ and $C$. sanguinea (48\%). This result is advantageous for $H$. axyridis because it causes indirectly increase in the prole.

Cardoso \& Lázzari (2003) researched C. sanguinea feeding of Cinara spp. at $25^{\circ} \mathrm{C}$, and found a longer incubation period of 4 days, in comparison with 3.20 
days in this study. In the current study, the larval stage duration (9.26 days) was longer than those reported by Cardoso \& Lázzari (2003) (8.6 days) and Santa-Cecilia et al. (2001) (males 8.2 days, and females 8.5 days) for $C$. sanguinea feeding on Schizaphis graminum (Rondani) (Hemiptera: Aphididae) at $25^{\circ} \mathrm{C}$. In this species, a longer pupal period was observed by Cardoso \& Lázzari (2003) (4.7 days), but the authors did not make reference to the pre-pupal period, which was probably included in this count. Santa-Cecilia et al. (2001) obtained a shorter time for pupal stage, 3.0 days for both sexes, in comparison to 3.77 days in the present study. Despite the small differences between the duration of each stage, the egg-adult time (17.40 days) was close to the 17.5 days found by Cardoso \& Lázzari (2003) for C. sanguinea kept at $25^{\circ} \mathrm{C}$.

Embryonic development of 2.97 days for $H$. axyridis was similar to that obtained by Abdel-Salam \& Abdel-Baky (2001) with species feeding on Sitotroga cerealella fresh and frozen grain moth eggs at $27 \pm 1^{\circ} \mathrm{C}$, $75 \pm 5 \%$ relative humidity, and 16:8-hour photophase (2.8 to 3.1 days).Also, embryonic development obtained in the present work was similar to that observed by Lanzoni et al. (2004) (2.8 days) for H. axyridis feeding on Myzus persicae (Sulzer) (Hemiptera: Aphididae) at $25 \pm 1{ }^{\circ} \mathrm{C}, 60-80 \%$ relative humidity, and $16: 8$-hour photophase, but less than the 3.4 days reported by Castro et al. (2011), for H. axyridis feeding on Cinara atlantica (Wilson) (Hemiptera: Aphididae) at $25 \pm 1^{\circ} \mathrm{C}$, $70 \pm 10 \%$ relative humidity, and 12 -hour photophase. The duration of the larval period of this species $(9.38$ days) was lesser than that reported by other authors:

Table 1. Development periods (days) of Cycloneda sanguinea, Harmonia axyridis, and Hippodamia convergens feeding on eggs of Anagasta kuehniella, at $24.5 \pm 1^{\circ} \mathrm{C}$, $70 \pm 10 \%$ relative humidity, and 12-hour photophase

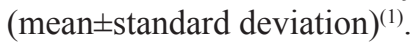

\begin{tabular}{lrrrrr}
\hline Stage & C. sanguinea & H. axyridis & H. convergens & Chi-squared & p-value \\
\hline Egg & $3.20 \pm 0.20 \mathrm{~b}$ & $2.97 \pm 0,08 \mathrm{c}$ & $3.21 \pm 0.15 \mathrm{a}$ & 22.26 & 0.01 \\
$1^{\text {st }}$ instar & $2.88 \pm 0.31 \mathrm{~b}$ & $2.64 \pm 0.19 \mathrm{c}$ & $3.26 \pm 0.16 \mathrm{a}$ & 39.10 & 0.01 \\
$2^{\text {nd }}$ instar & $1.80 \pm 0.20 \mathrm{c}$ & $1.83 \pm 0.11 \mathrm{~b}$ & $2.11 \pm 0.08 \mathrm{a}$ & 20.91 & 0.01 \\
$3^{\text {rd }}$ instar & $1.98 \pm 0.06 \mathrm{~b}$ & $1.97 \pm 0.07 \mathrm{c}$ & $2.35 \pm 0.11 \mathrm{a}$ & 40.52 & 0.01 \\
$4^{\text {th }}$ instar & $2.60 \pm 0.08 \mathrm{c}$ & $2.94 \pm 0.29 \mathrm{~b}$ & $3.30 \pm 0.14 \mathrm{a}$ & 55.84 & 0.01 \\
Pre-pupal & $1.17 \pm 0.08 \mathrm{a}$ & $1.09 \pm 0.09 \mathrm{~b}$ & $1.07 \pm 0.03 \mathrm{c}$ & 7.04 & 0.05 \\
Pupal & $3.77 \pm 0.03 \mathrm{c}$ & $4.75 \pm 0.12 \mathrm{a}$ & $4.48 \pm 0.11 \mathrm{~b}$ & 123.05 & 0.01 \\
Egg-dult & $17.40 \pm 0.24 \mathrm{c}$ & $18.19 \pm 0.44 \mathrm{~b}$ & $19.78 \pm 0.25 \mathrm{a}$ & 142.70 & 0.01 \\
\hline
\end{tabular}

${ }^{(1)}$ Means followed by equal letters in the lines do not differ by the $t$ test, at 1 or $5 \%$ probability.
10.1 days, Santos et al. (2009), 10.5 days, Lanzoni et al. (2004); between 11.2 and 13.4 days, Abdel-Salam \& Abdel-Baky (2001); and 13.1 days, Castro et al. (2011). Harmonia axyridis remained pupated for 4.75 days, close to the period found by Santos et al. (2009) for this species feeding on A. kuehniella eggs at $27^{\circ} \mathrm{C}(4.1$ days), Castro et al. (2011) (4.7 days), and Abdel-Salam $\&$ Abdel-Baky (2001) (4.9 to 6.0 days), but lesser than the 6.6 days reported by Lanzoni et al. (2004), who added the pre-pupal period. The value of 18.19 days, obtained for the egg-adult cycle, is close to the results by Abdel-Salam \& Abdel-Baky (2001) (18.9 to 22.5 days), and by Lanzoni et al. (2004) (19.8 days), and lesser than the value obtained by Castro et al. (2011) (22.3 days). The sex ratio (54\%) of $H$. axyridis was higher than that observed by Lanzoni et al. (2004) which was $39 \%$.

Embryonic period of 3.21 days of $H$. convergens coincided with that found by Kato et al. (1999) in A. kuehniella at $25^{\circ} \mathrm{C}$ (3.1 days). Larval stage duration of $H$. convergens (11.02 days) was approximately the same as the results by Cardoso \& Lázzari (2003) at $25^{\circ} \mathrm{C}$ (10.9 days), and shorter than that reported by Kato et al. (1999) (13.7 days). The duration of 4.48 days for the pupal period was similar to the 4.5 days obtained by Kato et al. (1999), and shorter compared to the 6.3 days determined by Cardoso \& Lázzari (2003), who added to this time the pre-pupal stage. Hippodamia convergens sex ratio (50\%) was lower than the $60 \%$ proportion found by Kato et al. (1999).

First and second instar larvae, which were more prone to intraguild predation attack and cannibalism, showed a slow development which was injurious for $H$. convergens, in comparison to the other species. With respect to biological control, Lanzoni et al. (2004) considered the advantage of the longer duration of the $4^{\text {th }}$ instar because, in this phase, the Coccinellini show high predatory activity. The authors obtained a higher value for $H$. axyridis than for $H$. variegata and $A$. bipunctata, unlike in the present study, which included $H$. convergens. However, the most rapid development of $1^{\text {st }}$ and $2^{\text {nd }}$ instar larvae of $H$. axyridis was found in both studies, which can be a positive factor for the species, since in the early stages larvae are more subject to predation.

Harmonia axyridis (49.2\%) exhibited the highest percentage for mortality rate, followed by $H$. convergens $(49.0 \%)$, and C. sanguinea $(42.0 \%)$. 
This highest rate in the three species corresponded to a high number of nonviable eggs (Figure 1). Regarding the survival of immature stages, two factors contributed to the high embryonic mortality rate in the present study, which are: cannibalism by larvae that hatched earlier; and the high percentage of infertile eggs laid by longer-living females, mainly among $H$. axyridis. The low percentage of survival, due to low viability of eggs, was also observed by Lanzoni et al. (2004) in evaluating $H$. axyridis, $H$. variegata and $A$. bipunctata.

Cardoso \& Lázzari (2003) followed the development of 20 eggs of $C$. sanguinea, at $25^{\circ} \mathrm{C}$, and found a high viability of $93.3 \%$, in comparison with $55.2 \%$ in the present study. For $H$. axyridis, a viability of $52.4 \%$ was similar to $53.0 \%$ as reported by Lanzoni et al. (2004) in 42 eggs, and less than the $90.7 \%$ found by Castro et al. (2011) at $25^{\circ} \mathrm{C}$. Among the three evaluated species, $H$. convergens exhibited the best performance for viability, at $65.4 \%$, which was lower than the value (86.3\%) found by Kato et al. (1999) in A. kuehniella.

Few studies emphasize egg-adult survival. In the present study, egg-adult survival for $C$. sanguinea $(42.0 \%)$ was lower than that described by Cardoso \& Lázzari (2003) of $78.3 \%$ at $25^{\circ} \mathrm{C}$; and in H. Axyridis, the rate of $49.2 \%$ was similar to the $49.4 \%$ rate found by Lanzoni et al. (2004), but lower than the results by Abdel-Salam \& Abdel-Baky (2001), which were

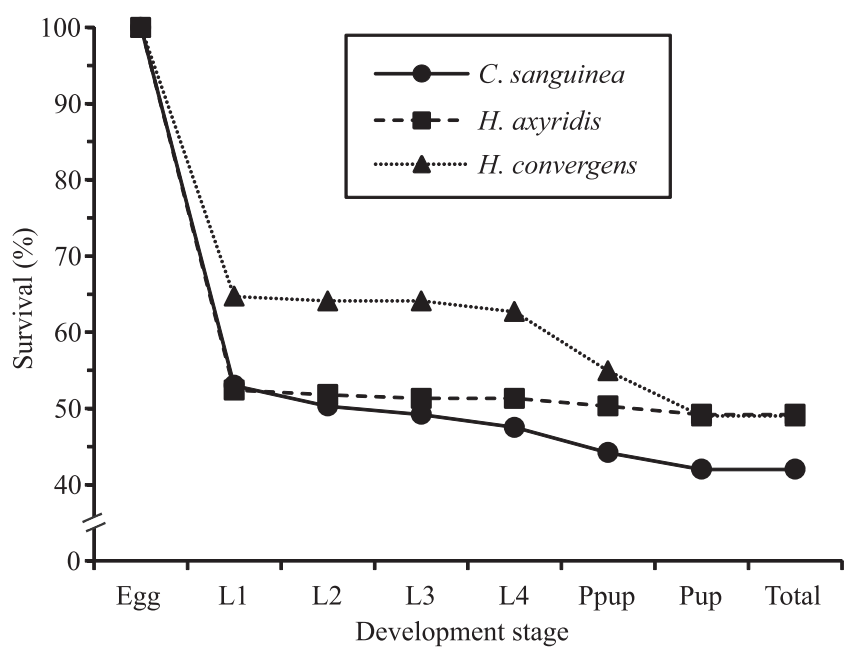

Figure 1. Survival rate of immature stages of Cycloneda sanguinea, Harmonia axyridis, and Hippodamia convergens fed eggs of Anagasta kuehniella, at $24.5 \pm 1^{\circ} \mathrm{C}, 70 \pm 10 \%$ relative humidity, and 12-hour photophase. between 84 to $80 \%$, and by Castro et al. (2011) which was $90.7 \%$.

Regarding the mean longevity of adults, $H$. convergens appeared deficient in comparison with the other species, and no significant difference was observed between lifespan of females of $C$. sanguinea and $H$. axyridis (Table 2 ). However, for males, lifespan was longer in $H$. axyridis, followed by $C$. sanguinea and $H$. convergens.

The mean period of pre-oviposition was the longest in $C$. sanguinea, and similar for $H$. axyridis and $H$. convergens. $H$. axyridis had the longest oviposition time, and the result for $C$. sanguinea was statistically similar as that of the two other species. The post-oviposition period was similar between the coccinellids.

Considering the reproductive parameters, $H$. axyridis showed the best performance in all aspects. For fecundity, the number of eggs laid by $H$. convergens was statistically similar to that of $C$. sanguinea. Taking into account the number of viable eggs, $H$. convergens and $C$. sanguinea had similar results; and for the number of eggs per oviposition, $H$. convergens superseded $C$. sanguinea (Table 2).

Cardoso \& Lázzari (2003) observed that adults of C. sanguinea had longevity of 167.1 days when kept at $20^{\circ} \mathrm{C}$ and, despite the difference in temperature, these results are close to the values of 147.0 (females) and 162.8 days (males) found in the present study.

Adults of $H$. axyridis lived a mean of 148.9 (females) and 220.3 days (males); these values were much higher than those reported by the following authors: Lanzoni et al. (2004), who observed that the lowest longevity was 44 days; by Abdel-Salam \& Abdel-Baky (2001), who found 43.9 (fresh eggs) and 62.2 days (frozen eggs); by Castro et al. (2011) with 89.1 days; and by Santos et al. (2009), who observed variations between 74.1 and 76.2 days (females), and 67.3 and 70.3 days (males), at $27^{\circ} \mathrm{C}$. This long life time made the oviposition period (129.9 days) longer than that found by Lanzoni et al. (2004) (13.7 days), Abdel-Salam \& Abdel-Baky (2001) (45.3 to 49.0 days), Santos et al. (2009) (47.3 days), and Castro et al. (2011) (76.87 days).

The pre-oviposition period (9.4 days) was similar to the results observed by Abdel-Salam \& Abdel-Baky (2001) (between 8.1 and 9.5 days), and Santos et al. (2009) (9.8 days), but longer than the 7.4 days observed by Lanzoni et al. (2004), and 5.8 days by Castro et al. 
(2011). The post-oviposition period of 9.8 days was about the same as that of 10.8 days found by Castro et al. (2011), shorter compared to the results of Santos et al. (2009) (17.0 days), and longer than that of 5.1 to 6.8 days reported by Abdel-Salam \& Abdel-Baky (2001). This long oviposition period directly influenced fecundity of females that oviposited a mean of $4,453.5$ eggs, a much higher number than that reported by Lanzoni et al. (2004) (560.5), Castro et al. (2011) (614.0), Abdel-Salam \& Abdel-Baky (2001) (606.6 to 715.3), and Santos et al. (2009) (887.6). A mean of 48.79 eggs per oviposition was determined, which is higher than the value observed by 18.5 of Castro et al. (2011).

Hippodamia convergens females had longevity of 89.4 days, and the males had 63.2 days; these values were coincident with those observed by Kato et al. (1999), who found a mean longevity of 88.9 days for adults fed A. kuehniella. Pre-oviposition and oviposition periods, 12.2 and 72.1 days were close to those obtained by Kato et al. (1999), which were 12.8 and 68.8 days; but a post-oviposition of 5.1 days was shorter than that of 11.1 days found by the same authors. The number of eggs per oviposition (27.62) of $H$. convergens was higher than the value of 11.0 eggs reported by Kato et al. (1999) for feeding with $A$. kuehniella.

The rate survival $\left(1_{\mathrm{x}}\right)$ of $C$. sanguinea stayed the same up to the $96^{\text {th }}$ day, when other deaths gradually occurred after a prolonged oviposition period, and the last individual died on the $201^{\text {th }}$ day (Figure $2 \mathrm{~A}$ ). The oviposition period occurred between the $17^{\text {th }}$ and the $173^{\text {th }}$ day with a peak on the $42^{\text {th }}$ day ( 22.1 eggs). The highest values of specific fertility $\left(\mathrm{m}_{\mathrm{x}}\right)$ were observed from the $29^{\text {th }}$ to the $81^{\text {st }}$ day, when a gradual decrease occurred up to the last oviposition, except for the $114^{\text {th }}$ day with $\mathrm{m}_{\mathrm{x}}$ of 5.88 .

Harmonia axyridis had a survival rate constant $\left(1_{\mathrm{x}}\right)$ up to the $85^{\text {th }}$ day, with a gradual decrease up to the $214^{\text {th }}$ day, followed by a sudden decline, showing again a decrease up to the $242^{\text {nd }}$ day. The oviposition period occurred between the $10^{\text {th }}$ and the $197^{\text {th }}$ day, with a peak on the $35^{\text {th }}$ day ( 81.7 eggs). Specific fertility $\left(\mathrm{m}_{\mathrm{x}}\right)$ was the highest on the $15^{\text {th }}$ to the $98^{\text {th }}$ day, which afterwards markedly declined (Figure $2 \mathrm{~B}$ ). For Castro et al. (2011), H. axyridis (feeding C. atlantica at $25^{\circ} \mathrm{C}$ ) found $1_{\mathrm{x}}$ constant up to the $59^{\text {th }}$ day, and the last individual died at the $124^{\text {th }}$ day. These insects laid eggs from the $4^{\text {th }}$ to the $118^{\text {th }}$ days with high $m_{x}$ from the $7^{\text {th }}$ to the $34^{\text {th }}$ days. Abdel-Salam \& Abdel-Baky (2001) evaluated the life table parameters of $H$. axyridis, comparing results among insects when feeding on fresh and frozen eggs of grain moth $(S$. cerealella $)$. These authors obtained $l_{x}$ constant until the $34^{\text {th }}$ and $30^{\text {th }}$ days, the last individuals died after the $52^{\text {th }}$ and $49^{\text {th }}$ days in fresh and frozen eggs, respectively. Pre-oviposition period observed by Abdel-Salam \& Abdel-Baky (2001) was of 8.1 to 9.5 days; thereafter $H$. axyridis remained laying eggs until almost to the death of individuals, and the higher $\mathrm{m}_{\mathrm{x}}$ found was 18.44 ( $2^{\text {nd }}$ day of oviposition $)$ and 17.44 ( $8^{\text {th }}$ day of oviposition) for fresh and frozen eggs, respectively.

The survival rate $\left(1_{\mathrm{x}}\right)$ recorded for $H$. convergens remained constant up to the $44^{\text {th }}$ day and, then,

Table 2. Biological periods, longevity (days), and reproductive parameters in adults of Cycloneda sanguinea, Harmonia axyridis, and Hippodamia convergens feeding on eggs of Anagasta kuehniella, at $24.5 \pm 1{ }^{\circ} \mathrm{C}, 70 \pm 10 \%$ relative humidity, and 12-hour photophase (mean \pm standard deviation $)^{(1)}$.

\begin{tabular}{|c|c|c|c|c|c|c|}
\hline Parameter & C. sanguinea & H. axyridis & H. convergens & Test F & Test $\chi^{2}$ & p-value \\
\hline \multicolumn{7}{|l|}{ Longevity } \\
\hline Female & $147.00 \pm 12.41 \mathrm{a}$ & $148.90 \pm 6.22 \mathrm{a}$ & $89.40 \pm 18.99 b$ & 5.79 & - & 0.01 \\
\hline Male & $162.80 \pm 18.97 \mathrm{~b}$ & $220.30 \pm 3.56 \mathrm{a}$ & $63.20 \pm 11.93 c$ & - & 25.18 & 0.01 \\
\hline \multicolumn{7}{|l|}{ Period } \\
\hline Pre-oviposition & $24.30 \pm 1.36 \mathrm{a}$ & $9.50 \pm 0.42 b$ & $12.20 \pm 8.89 b$ & - & 12.73 & 0.01 \\
\hline Oviposition & $108.70 \pm 14.95 \mathrm{ab}$ & $129.90 \pm 6.95 \mathrm{a}$ & $72.10 \pm 16.70 b$ & 5.54 & - & 0.01 \\
\hline Post-oviposition & $14.00 \pm 6.85 \mathrm{a}$ & $9.50 \pm 2.08 \mathrm{a}$ & $5.10 \pm 3.54 \mathrm{a}$ & ns & ns & - \\
\hline \multicolumn{7}{|l|}{ Reproductive } \\
\hline Fecundity & $998.00 \pm 99.40 \mathrm{~b}$ & $4453.50 \pm 301.90 \mathrm{a}$ & $1189.40 \pm 191.74 b$ & 36.67 & - & 0.001 \\
\hline Fertility & $549.90 \pm 90.70 \mathrm{~b}$ & $2340.50 \pm 114.32 \mathrm{a}$ & $778.40 \pm 81.85 b$ & 35.11 & - & 0.001 \\
\hline Eggs/oviposition & $17.94 \pm 0.34 \mathrm{c}$ & $48.79 \pm 3.90 \mathrm{a}$ & $27.62 \pm 2.03 \mathrm{~b}$ & 43.12 & - & 0.01 \\
\hline
\end{tabular}

${ }^{(1)}$ Means followed by equal letters in the lines do not differ by Tukey test, at $5 \%$ probability, or by the t test, at 1 or $5 \%$ probability. $\chi^{2}$, chi-squared. 
decreased markedly and stabilized between the $85^{\text {th }}$ and the $128^{\text {th }}$ day until the death of the last individual on the $187^{\text {th }}$ day. The oviposition period occurred between the $5^{\text {th }}$ and the $101^{\text {st }}$ day with a peak on the $30^{\text {th }}$ day (33.6 eggs). The highest values of specific fertility $\left(\mathrm{m}_{\mathrm{x}}\right)$ occurred from the $28^{\text {th }}$ to the $92^{\text {nd }}$ day and, in a few days females stopped ovipositing (Figure 2 C). Golizadeh \& Jafari-Behi (2012) compared the performance of Hippodamia variegata (Goeze, 1777) feeding on three species of aphids [Aphis gossypii Glover, Aphis fabae Scopoli e Macrosiphum rosae (L.) (Hemiptera: Aphididae)] at $25 \pm 1^{\circ} \mathrm{C}, 65 \pm 5 \%$ relative humidity, and 16:8-hour photophase. These authors observed that aphid species significantly affect the parameters of the life table, but in all three treatments, the insects showed a decrease of $1_{x}$ before they begin
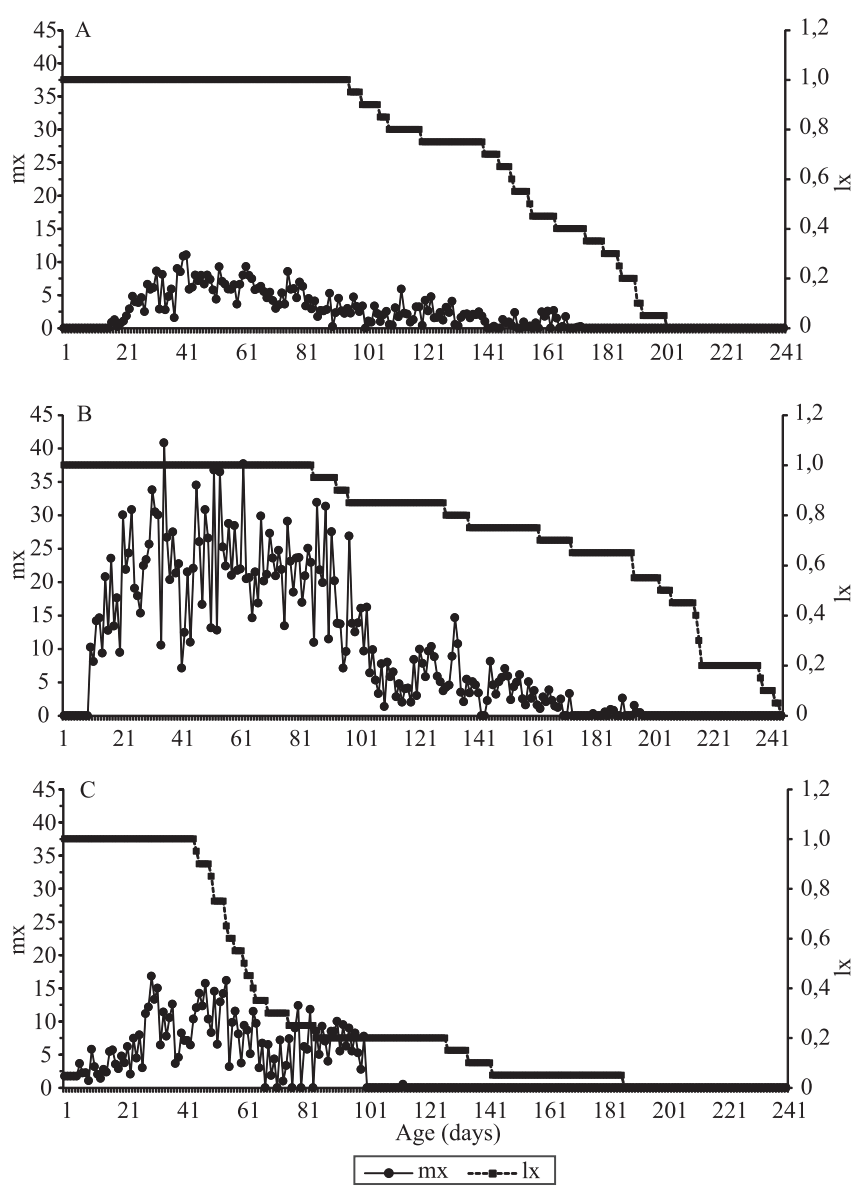

Figure 2. A, Cycloneda sanguinea; B, Harmonia axyridis; C, Hippodamia convergens. Specific fertility $\left(\mathrm{m}_{\mathrm{x}}\right)$ and survival rate $\left(1_{\mathrm{x}}\right)$ of coccinellids feeding on eggs of Anagasta kuehniella, at $24.5 \pm 1^{\circ} \mathrm{C}, 70 \pm 10 \%$ relative humidity, and 12-hour photophase. to lay eggs, remaining constant for about 20 to 70 days, and then they went into gradual decline until the latter's coccinellid death (between 90 to 100 days). $H$. variegata showed oviposition period between the $20^{\text {th }}$ and the $90^{\text {th }}$ days with $\mathrm{m}_{\mathrm{x}}$ higher when fed A. fabae. In the present study, the three coccinellids species showed a greater longevity and a larger oviposition period than the results found by other authors.

The shortest time interval between each generation (T) was found for $H$. convergens (38.34 days), followed by $C$. sanguinea (51.43 days) and $H$. axyridis (55.39 days) (Table 3). The interval between generations of $H$. axyridis was higher than those obtained by: Lanzoni et al. (2004), which was 38.81 days, when this species fed $M$. persicae at $25^{\circ} \mathrm{C}$; Castro et al. (2011), which was 39.48 days; and by Abdel-Salam \& Abdel-Baky (2001), between 37.87 at 45.04 days, for fresh and frozen eggs of $S$. cerealella, respectively. An intermediate value was obtained, when comparing the " $\mathrm{T}$ " of $H$. convergens (38.34 days) with certain results of $H$. variegata when fed aphids. Lanzoni et al. (2004) registered 41.88 days, and Golizadeh \& Jafari-Behi (2012) reported values between 30.23 and 33.37 days, according to the consumed aphid.

Castro et al. (2011) noted that $H$. axyridis in Brazil is a multivoltine species, which means that it shows several generations per year, depending on the region where it is located. Thus, temperature and type of food are factors that are influencing the interval between each generation in this insect.

The longer life cycle was compensated in the species $H$. axyridis by the high net reproductive rate $\left(R_{\mathrm{o}}\right)$ of 2,226.89, which is about five times greater than that of $H$. convergens and $C$. sanguinea (Table 3 ). For $H$. convergens, the value was higher than that

Table 3. Estimated life Table parameters of Cycloneda sanguinea, Harmonia axyridis, and Hippodamia convergens feeding on eggs of Anagasta kuehniella, at $24.5 \pm 1^{\circ} \mathrm{C}$, $70 \pm 10 \%$ relative humidity, and 12 -hour photophase.

\begin{tabular}{lccc}
\hline Parameter $^{(1)}$ & C. sanguinea & H. axyridis & H. convergens \\
\hline $\mathrm{T}$ & 51.43 & 55.49 & 38.34 \\
$\mathrm{R}_{\mathrm{o}}$ & 499.00 & 2226.89 & 450.15 \\
$\mathrm{r}_{\mathrm{m}}$ & 0.12 & 0.13 & 0.16 \\
$\lambda$ & 1.1283 & 1.1490 & 1.1727 \\
$\mathrm{TD}$ & 5.73 & 4.99 & 4.35 \\
\hline
\end{tabular}

${ }^{(1)} \mathrm{T}$, time interval between each generation; $\mathrm{R}_{\mathrm{o}}$, net reproductive rate; $\mathrm{r}_{\mathrm{m}}$, innate capacity to increase in numbers; $\lambda$, finite ratio of population increase; $\mathrm{TD}$, population doubling time. 
obtained for $H$. variegata by Lanzoni et al. (2004) of 52.75, and by Golizadeh \& Jafari-Behi (2012), which was varying between 183.23 and 236.54 . H. axyridis, in this present study, showed a very high value in relation to those by: Lanzoni et al. (2004), 26.27; Castro et al. (2011), of 278.03; and Abdel-Salam \& Abdel-Baky (2001), between 234.96 at 289.11. Although only one generation of laboratory has been monitored, the high value of $\mathrm{R}_{\mathrm{o}}$ obtained by exotic species shows that this insect had a rapid adaptation to diet of A. kuehniella eggs, and that its potential for population increase is much higher than those of the other coccinellids.

Cycloneda sanguinea and $H$. axyridis displayed close values of intrinsic growth rate $\left(\mathrm{r}_{\mathrm{m}}\right), 0.12$ and 0.13 , respectively; while a higher value (0.16) was shown by $H$. convergens (Table 3 ). This indicates that although the predator survives, grows, and reproduces with an alternative diet of $A$. kuehniella eggs, it has a limited population growth when receives a natural diet. The intrinsic rate increase of $H$. axyridis was higher than that found by Lanzoni et al. (2004) which was 0.09, and it approximates the results by Abdel-Salam \& Abdel-Baky (2001), which were beetwen 0.12 at 0.15 for fresh and frozen eggs of $S$. cerealella, respectively, and by Castro et al. (2011), which was 0.14 at $25^{\circ} \mathrm{C}$. The $\mathrm{r}_{\mathrm{m}}$ of 0.16 for $H$. convergens was superior to the results obtained by Lanzoni et al. (2004) for $H$. variegata (0.114), and approximates the values recorded for Golizadeh \& Jafari-Behi (2012) (0.156 a 0.183).

According Southwood \& Henderson (2000), from the life table parameters, the intrinsic rate of increase is the most useful one to compare the potential population growth, under specific conditions of temperature and food, and reflects the overall effects of predation on the development, reproduction characteristics, and survival of a population. According to Andrewartha \& Birch (1954), the higher the value of $r_{m}$, more effective will be the species in a certain environment. In this study, $H$. convergens showed to be more successful when fed A. kuehniella eggs under the conditions of temperature, relative humidity and constant photophase.

The higher finite ratio of population increase $(\lambda)$ indicates the number of females that are added to the population by each female. Hippodamia convergens had the highest values of increase, followed by $H$. axyridis and $C$. sanguinea (Table 3 ). To this rate, $H$. axyridis had similar value to that obtained by
Castro et al. (2011) 1.1502 at $25^{\circ} \mathrm{C}$, and intermediate to the results of Abdel-Salam \& Abdel-Baky (2001), from 1.166 to 1.128 , for fresh and frozen eggs of $S$. cerealella, respectively. According to Golizadeh \& Jafari-Behi (2012), in H. variegata these values varied between 1.201 and 1.198 depending on the consumed aphid; these values are close to those obtained for $H$. convergens in the present study. The $\lambda$ values confirm the results of $R_{0}$, indicating that the population of the three species increased from one generation to another and, thus, found ideal conditions for their development.

The least time needed for the population to double in number (TD) was observed for $H$. convergens, followed by $H$. axyridis and $C$. sanguinea (Table 3 ). Other authors found similar values to those found here for TD. Castro et al. (2011) found 4.95, and Abdel-Salam \& Abdel-Baky (2001) found between 4.53 and 5.72 for H. axyridis; Golizadeh \& Jafari-Behi (2012) found between 3.79 and 4.44 for $H$. variegata.

In general, the biological characteristics of $H$. axyridis favor the invasion and establishment of this species in Brazil, corroborating the results obtained by researchers in other countries. Harmonia axyridis in comparison to $H$. convergens and $C$. sanguinea showed a shorter duration of early larval stages, greater longevity of adults and, consequently, a longer oviposition period, high rates of fecundity and fertility, and a greater number of eggs per oviposition. Meanwhile, other results such as duration of $4^{\text {th }}$ instar, survival percentage of immatures, and shorter pre-oviposition period were similar to those shown for H. convergens.

Life table of fertility showed that $H$. convergens had higher values, although close, to those of $H$. axyridis, except for the high value for the net reproductive rate $\left(\mathrm{R}_{\mathrm{o}}\right)$ of $H$. axyridis, showing that the potential for population increase of the invasive species was very high in comparison with the other two evaluated species. Cycloneda sanguinea has fragility when compared to $H$. axyridis and $H$. convergens. The nutritional quality of the alternative diet might have affected the performance of $C$. sanguinea.

\section{Conclusion}

The greatest longevity, the longest oviposition period, and the greatest number of eggs and viability of instars of the exotic Harmonia axyridis are very

Pesq. agropec. bras., Brasília, v.49, n.1, p.1-10, jan. 2014

DOI: 10.1590/S0100-204X2014000100001 
important characteristics which increased the net reproduction rate, which brings benefits for this species population, in comparison to Hippodamia convergens and Cycloneda sanguinea.

\section{Acknowledgments}

To Conselho Nacional de Desenvolvimento Científico e Tecnológico (CNPq), for fellowship granted (Process n. 157826/2011-2); to the Laboratório de Biologia de Insetos, Escola Superior de Agricultura Luiz de Queiroz (Esalq); and to Cristina Jensen Ramos, for donating the A. kuehniella eggs.

\section{References}

ABDEL-SALAM, A.H.; ABDEL-BAKY, N.F. Life table and biological studies of Harmonia axyridis Pallas (Col., Coccinellidae) reared on the grain moth eggs of Sitotroga cerealella Olivier (Lep., Gelechiidae). Journal of Applied Entomology, v.125, p.455-462, 2001. DOI: 10.1046/j.1439-0418.2001.00574.x.

ALMEIDA, L.M. de; RIBEIRO-COSTA, C.S. Coleópteros predadores (Coccinellidae). In: PANIZZI, A.R.; PARRA, J.R. (Ed.). Bioecologia e nutrição de insetos: base para o manejo integrado de pragas. Brasília: Embrapa Informação Tecnológica, 2009. p.931-968.

ALMEIDA, L.M. de; SILVA, V.B. da. Primeiro registro de Harmonia axyridis (Pallas) (Coleoptera, Coccinellidae): um coccinelídeo originário da região Paleártica. Revista Brasileira de Zoologia, v.19, p.941-944, 2002. DOI: 10.1590/ S0101-81752002000300031.

AMAT-GARCÍA, G.; AMAT-GARCÍA, E.; ARIZA-MARÍN, E. Insectos invasores en los tiempos de cambio climático. Innovación y Ciencia, v.18, p.44-53, 2011.

ANDREWARTHA, H.G.; BIRCH, L.C. The innate capacity for increase in numbers. In: ANDREWARTHA, H.G.; BIRCH, L.C. (Ed.). The distribution and abundance of animals. Chicago: University of Chicago, 1954. 793p.

BERNARDI, O.; GARCIA, M.S.; SILVA, E.J.E. e; ZAZYCKI, L.C.F.; BERNARDI, D.; MIORELLI, D.; RAMIRO, G.A.; FINKENAUER, E. Coleópteros coletados com armadilhas luminosas e etanólicas em plantio de Eucalyptus spp. no sul do Rio Grande do Sul. Ciência Florestal, v.20, p.579-588, 2010.

CARDOSO, J.T.; LÁZZARI, S.M.N. Consumption of Cinara spp. (Hemiptera, Aphididae) by Cycloneda sanguinea (Linnaeus, 1763) and Hippodamia convergens Guérin-Méneville, 1842 (Coleoptera, Coccinellidae). Revista Brasileira de Entomologia, v.47, p.559-562, 2003. DOI: 10.1590/S0085-56262003000400004.

CASTRO, C.F.; ALMEIDA, L.M.; PENTEADO, S.R.C. The impact of temperature on biological aspects and life table of Harmonia axyridis (Pallas) (Coleoptera: Coccinellidae). Florida Entomologist, v.94, p.923-932, 2011. DOI: 10.1653/024.094.0429.
GOLIZADEH, A.; JAFARI-BEHI, V. Biological traits and life table parameters of variegated lady beetle, Hippodamia variegata (Coleoptera: Coccinellidae) on three aphid species. Applied Entomology and Zoology, v.47, p.199-205, 2012. DOI: 10.1007/ s13355-012-0108-8.

GONZÁLEZ, G.; KONDO, T. Primer registro de la especie invasora Harmonia axyridis (Pallas) (Coleoptera: Coccinellidae) en Ecuador. Boletín de la Sociedad Entomológica Aragonesa, v.51, p.310, 2012.

GREZ, A.; ZAVIEZO, T.; GONZÁLEZ, G.; ROTHMANN, S. Harmonia axyridis in Chile: a new threat. Ciencia e Investigación Agraria, v.37, p.145-149, 2010. DOI: 10.4067/ S0718-16202010000300013.

GUERREIRO, J.C.; BUENO, P.R.R.; BERTI FILHO, E.; BUSOLI, A.C. Ocorrência estacional das principais espécies de Coccinellidae predadores de Toxoptera citricida nos citros. Revista Científica Eletrônica de Agronomia, v.4, p.1-14, 2005.

IANNACONE, J.; PERLA, D. Invasión del depredador Harmonia Axyridis (Coleoptera: Coccinellidae) y una evaluación del riesgo ambiental en el Perú. The Biologist, v.9, p.213-233, 2011.

KATO, C.M.; BUENO, V.H.P.; MORAES, J.C.; AUAD, A.M. Criação de Hippodamia convergens Guérin-Meneville (Coleoptera: Coccinellidae) em ovos de Anagasta kuehniella (Zeller) (Lepidoptera: Pyralidae). Anais da Sociedade Entomológica do Brasil, v.28, p.455-459, 1999. DOI: 10.1590/ S0301-80591999000300010.

$\mathrm{KOCH}$, R.L. The multicolored Asian lady beetle, Harmonia axyridis: a review of its biology, uses in biological control, and non-target impacts. Journal of Insect Science, v.3, p.1-16, 2003.

KOCH, R.L.; FERNANDES, M.G.; DUTRA, C.C. First confirmed record of Harmonia axyridis (Pallas, 1773) (Coleoptera: Coccinellidae) in the state of Mato Grosso do Sul, Brazil. CheckList, v.7, p.476-477, 2011.

KOCH, R.L.; GALVAN, T.L. Bad side of a good beetle: the North American experience with Harmonia axyridis. BioControl, v.53, p.23-35, 2008. DOI: 10.1007/s10526-007-9121-1.

KOCH, R.L.; VENETTE, R.C.; HUTCHISON, W.D. Invasions by Harmonia axyridis (Pallas) (Coleoptera: Coccinellidae) in the Western hemisphere: implications for South America. Neotropical Entomology, v.35, p.421-434, 2006. DOI: 10.1590/ S1519-566X2006000400001.

LANZONI, A.; ACCINELLI, G.; BAZZOCCHI, G.G.; BURGIO, G. Biological traits and life table of the exotic Harmonia axyridis compared with Hippodamia variegata and Adalia bipunctata (Col.: Coccinellidae). Journal of Applied Entomology, v.128, p.298-306, 2004. DOI: 10.1111/j.1439-0418.2004.00847.x.

MARTINS, C.B.C.; ALMEIDA, L.M.; ZONTA-DE-CARVALHO, R.C.; CASTRO, C.F.; PEREIRA, R.A. Harmonia axyridis: a threat to Brazilian Coccinellidae? Revista Brasileira de Entomologia, v.53, p.663-671, 2009. DOI: 10.1590/S0085-56262009000400018.

MEISNER, M.H.; HARMON, J.P.; IVES, A.R. Response of coccinellid larvae to conspecific and heterospecific larval tracks: a mechanism that reduces cannibalism and intraguild predation. 
Environmental Entomology, v.40, p.103-110, 2011. DOI: 10.1603/EN10211.

MENDES, S.; CERVIÑO, M.N.; BUENO, V.H.P.; AUAD, A.M. Diversidade de pulgões e de seus parasitoides e predadores na cultura da alfafa. Pesquisa Agropecuária Brasileira, v.35, p.1305-1310, 2000. DOI: 10.1590/S0100-204X2000000700003.

MICHELOTTO, M.D.; SILVA, R.A. da; GUERREIRO, J.C.; BUSOLI, A.C. Diversidade e abundância de coccinelídeos em seis cultivares de algodoeiro (Gossypium hirsutum L.). Boletín de Sanidad Vegetal. Plagas, v.29, p.219-226, 2003.

MILlÉO, J.; SOUZA, J.M.T. de; BARBOLA, I. de F.; HUSCH, P.E. Harmonia axyridis em árvores frutíferas e impacto sobre outros coccinelídeos predadores. Pesquisa Agropecuária Brasileira, v.43, p.537-540, 2008. DOI: 10.1590/ S0100-204X2008000400013.

NEDVED, O.; KREJÈIK, S. Record of the ladybird Harmonia axyridis (Coleoptera: Coccinellidae) from Uruguay. Klapalekiana, v.46, p.203-204, 2010.

PELL, J.K.; BAVERSTOCK, J.; ROY, H.E.; WARE, R.L.; MAJERUS, M.E.N. Intraguild predation involving Harmonia axyridis: a review of current knowledge and future perspectives. BioControl, v.53, p.147-168, 2008. DOI: 10.1007/978-1-4020-6939-0_10.

PENTEADO, S. do R.C.; OLIVEIRA, E.B. de; LAZZARI, S.M.N. TabVida - sistema computacional para cálculo de parâmetros biológicos e de crescimento populacional de afídeos. Colombo: Embrapa Florestas, 2010. 30p. (Embrapa Florestas. Documentos, 203). Disponível em: <http://www. infoteca.cnptia.embrapa.br/bitstream/doc/870882/1/Doc203. pdf $>$. Acesso em: 17 set. 2013.
$\mathrm{R}$ DEVELOPMENT CORE TEAM. R: a language and environment for statistical computing. Vienna: R Foundation for Statistical Computing, 2011. Available at: <http://www.r-project. org/>. Accessed on: 18 Sep. 2013.

ROY, H.; MIGEON, A. Ladybeetles (Coccinellidae). BioRisk, v.4, p.293-313, 2010. DOI: 10.3897/biorisk.4.49.

SAINI, E.D. Presencia de Harmonia axyridis (Pallas) (Coleoptera: Coccinellidae) en la Provincia de Buenos Aires: aspectos biológicos y morfológicos. Revista de Investigaciones Agropecuarias, v.33, p.151-160, 2004.

SANTA-CECÍLIA, L.V.C.; GONÇALVES-GERVÁSIO, R.C.R.; TÔRRES, R.M.S.; NASCIMENTO, F.R. Aspectos biológicos e consumo alimentar de larvas de Cycloneda sanguinea (Linnaeus, 1763) (Coleoptera: Coccinellidae) alimentadas com Schizaphis graminum (Rondani, 1852) (Hemiptera: Aphididae). Ciência e Agrotecnologia, v.25, p.1273-1278, 2001.

SANTOS, N.R.P. dos; SANTOS-CIVIDANES, T.M. dos; CIVIDANES, F.J.; ANJOS, A.C.R. dos; OLIVEIRA, L.V.L. de. Aspectos biológicos de Harmonia axyridis alimentada com duas espécies de presas e predação intraguilda com Eriopis conexa. Pesquisa Agropecuária Brasileira, v.44, p.554-560, 2009. DOI: 10.1590/S0100-204X2009000600002.

SOUTHWOOD, T.R.E.; HENDERSON, P.A. The construction, description and analysis of age-specific life-tables. In: SOUTHWOOD, T.R.E.; HENDERSON, P.A. (Ed.). Ecological methods. $3^{\text {rd }}$. ed. Oxford: Blackwell Science, 2000.

VILCINSKAS, A.; STOECKER, K.; SCHMIDTBERG, H.; RÖHRICH, C.R.; VOGEL, H. Invasive harlequin ladybird carries biological weapons against native competitors. Science, v.340, p.862-863, 2013. DOI: $10.1126 /$ science. 1234032 .

Received on Octuber 14, 2013 and accepted on December 27, 2013

Pesq. agropec. bras., Brasília, v.49, n.1, p.1-10, jan. 2014

DOI: 10.1590/S0100-204X2014000100001 